\title{
Bentuk Komunikasi Pemasaran Digital ST22 Consulting
}

\author{
Graceica Octavia, Wulan Purnama Sari \\ graceica_octavia@ymail.com,wulanp@fikom.untar.ac.id
}

Fakultas Ilmu Komunikasi Universitas Tarumanagara

\begin{abstract}
Entering the current era of globalization, everyone is vying for the more productive. Supported digital media growing as a form of technological advances, the use of digital media is also utilized for commercial interests, one of which is to support the marketing communications. In former times only the large corporations that are able to perform the activities of marketing communications, digital media, a small company such as startup can do marketing communications activities. Like his thing ST22 Consulting as a startup in the field of sponsorship consultants can also do marketing communication activities. This research would like to see how this form of digital marketing communications made by ST22 Consulting. The object of the research is a form of digital marketing communications with research subjects is ST22 Consulting as a consultant Sponshorship. The current study qualitative descriptive nature with the theory used is the theory of marketing communications, digital marketing and new media, with a case study research methods. Based on the analysis done, ST22 Consulting marketing communications activities to market brand ST22Consulting to the community, establish the interaction, as well as communicating the products and services offered, especially to prospective clients and business partners. ST22 Consulting first determining the target audience, then assembles the content and determine the media or communication channels. And then the shape of the digital marketing communications made by ST22 Consulting is paid media, earned media and owned media.
\end{abstract}

Keywords: digital marketing, integrated marketing communication, new media

\begin{abstract}
Abstrak
Memasuki era globalisasi saat ini, setiap orang berlomba-lomba untuk semakin produktif. Didukung dengan semakin berkembangnya media digital sebagai wujud kemajuan teknologi, penggunaan media digital juga dimanfaatkan untuk kepentingan komersial, salah satunya untuk menunjang komunikasi pemasaran. Apabila dahulu hanya perusahaan besar yang mampu melakukan kegiatan komunikasi pemasaran, dengan adanya media digital, perusahaan kecil seperti startup pun bisa melakukan kegiatan komunikasi pemasaran. Seperti hal-nya ST22 Consulting sebagai startup dalam bidang konsultan sponsorship juga bisa melakukan kegiatan komunikasi pemasaran. Penelitian ini ingin melihat bagaimana bentuk komunikasi pemasaran digital yang dilakukan oleh ST22 Consulting. Obyek penelitian adalah bentuk komunikasi pemasaran digital dengan subyek penelitian adalah ST22 Consulting sebagai Konsultan Sponshorship. Penelitian ini bersifat kualitatif deskriptif dengan teori yang digunakan ialah teori komunikasi pemasaran, pemasaran digital dan new media, dengan metode penelitian studi kasus. Berdasarkan analisis yang dilakukan, ST22 Consulting melakukan kegiatan komunikasi pemasaran untuk memasarkan brand ST22Consulting kepada masyarakat, menjalin interaksi, juga mengkomunikasikan produk maupun jasa yang ditawarkan khususnya kepada calon klien dan mitra usaha. ST22 Consulting terlebih dahulu menentukan target audience, lalu meyusun konten dan menentukan media atau saluran komunikasi. Lalu bentuk komunikasi pemasaran digital yang dilakukan oleh ST22 Consulting adalah paid media, earned media dan owned media.
\end{abstract}

Kata Kunci: pemasaran digital, komunikasi pemasaran terintegrasi, Media baru 


\section{Pendahuluan}

Memasuki era globalisasi saat ini, membuat setiap orang berlomba-lomba untuk semakin produktif. Didukung dengan semakin berkembangnya media digital sebagai wujud kemajuan teknologi. Maraknya transaksi perdagangan melalui media online, juga sebagai bukti bahwa kita sudah memasuki era globalisasi. Tidak dapat dipungkiri, penggunaan media digital adalah suatu hal yang harus di era globalisasi saat ini, karena penggunaan media digital dinilai sangat membantu kehidupan seharihari. Kegiatan komunikasi menjadi semakin mudah, kemajuan teknologi yang pesat, memaksa kita untuk semakin gencar mengeksplorasi diri dengan memanfaatkan teknologi tersebut.

Bahkan saat ini, penggunaan media digital juga dimanfaatkan untuk kepentingan komersial, salah satunya untuk menunjang komunikasi pemasaran. Pengertian komunikasi pemasaran sendiri aplikasi komunikasi yang ditujukan untuk membantu kegiatan pemasaran sebuah perusahaan. Aplikasi tersebut sangat dipengaruhi oleh berbagai bentuk media yang digunakan. Komunikasi pemasaran dapat juga sebagai kegiatan komunikasi yang ditunjukan untuk menyampaikan pesan kepada konsumen dan pelanggan dengan menggunakan sejumlah media dan berbagai saluran yang dapat dipergunakan dengan harapan terjadinya tiga tahapan perubahan, yaitu : perubahan pengetahuan, perubahan sikap, dan perubahan tindakan yang dihendaki. Adapaun jenis media yang digunakan seperti : poster, banner, fliers, televisi, radio, majalah, dan surat kabar. Komunikasi pemasaran membahas beberapa masalah yang memiliki kaitan erat, dan yang akan mempengaruhi serta strategi aplikasi komunikasi dalam pemasaran. Somanegara (2008:72).

Kegiatan komunikasi pemasaran saat ini semakin dipermudah dengan adanya media digital. Apabila dahulu hanya perusahaan besar yang sanggup mengeluarkan kocek yang cukup besar untuk melakukan kegiatan komunikasi pemasaran. Saat ini, dengan adanya media digital, perusahaan kecil atau yang sekarang lebih kita kenal sebagai startup, mampu melakukan kegiatan komunikasi pemasaran.

Pengertian startup company sendiri ialah perusahaan berbasis teknologi informasi yang menyediakan jasa atau produk melalui offline atau online, disebutkan juga bahwa dengan berkembangnya keadaan zaman sekarang startup lebih dikenal dengan perusahaan kecil yang memiliki hosting dan domain berupa website atau blog. (Arjanti dan Mosal, 2012: 3)

ST22 Consulting adalah startup yang bergerak di bidang konsultan sponsorship. ST22 Consulting menjawab permasalahan anak muda dalam mencari sponsor untuk event. Tidak dipungkiri, untuk membuat suatu event yang baik, dibutuhkan dana sebagai salah satu unsur penopangnya. Dalam rangka pemenuhuan dana, maka dibutuhkan sponsor dari pihak eksternal. Tetapi, tidak semua semua penyelanggara event atau pensi berhasil mendapatkan cukup banyak sponsor. Oleh karena itu, banyak penyelenggara event yang mencari dana dengan cara tidak tepat seperti berjualan, menggalang dana, meminta sumbangan, dan lain-lain.

ST22 Consulting memilih media digital sebagai bentuk komunikasi pemasaran dikarenakan media digital dianggap sebagai media yang efisien dengan biaya anggaran yang cukup hemat dan melalui pemasaran digital, informasi mengenai produk ataupun jasa yang dipasarkan dapat diakses kapan pun, selain itu jangkauan yang didapatkan juga luas. 
Berdasarkan latar belakang permasalahan di atas, maka penulis merumuskan suatu permasalahan yaitu: Bagaimana bentuk komunikasi pemasaran ST22 Consulting? Tujuan penelitian untuk mengetahui bagaimana bentuk komunikasi pemasaran digital yang dilakukan oleh ST22 Consulting sebagai konsultan sponsorship di Indonesia.

Kerangka pemikiran yang digunakan dalam penelitian ini adalah bagaimana ST22 Consulting sebagai Konsultan Sponsorship menggunakan komunikasi pemasaran untuk kegiatan promosi. Dalam kegiatan komunikasi pemasaran, penggunaan word of mouth adalah hal yang cukup membantu menjangkau khalayak. Untuk menunjang kegiatan komunikasi pemasaran tersebut, dibutuhkan pemasaran digital. Untuk itu, ST22 Consulting membutuhkan bentuk pemasaran digital yang tepat agar komunikasi pemasaran efektif menjangkau khalayak.

Menurut Koesnadji (2016:86) marketing communication merupakan bentuk komunikasi yang bertujuan untuk memperkuat strategi pemasaran, guna meraih segmentasi yang lebih luas. Selain itu, kegiatan marketing communication adalah kegiatan yang ditujukan untuk memperkenalkan, menjalin maupun menciptakan interaksi antara perusahaan dengan mitra usaha maupun konsumen dan kegiatan tersebut, atau merupakan suatu usaha untuk mengkomunikasikan perusahaan, produk maupun jasa kepada pihak luar (mitra usaha, supplier maupun konsumen).

Sedangkan menurut Larry Percy (2008:26) dalam buku Strategic Intergrated Marketing Communication, perencanaan strategis untuk IMC melibatkan proses lima langkah. Pertama, mengidentifikasi dan memilih target yang tepat, selanjutnya menentukan bagaimana mereka (pelanggan) membuat keputusan merek, menetapkan bagaimana mereka akan diposisikan dalam komunikasi pemasaran, dan pilih manfaat untuk mendukung posisi itu, kemudian mengatur strategi yang mengoptimalkan pengiriman dan pengolahan pesan.

Menurut Joseph (2011: 32) digital marketing merupakan suatu keadaan dimana pemasar harus menguasai tiga hal dari konsumen yaitu pikiran, hati dan semangat mengacu kepada pemasaran yang bersifat elektronik berbasis internet. Memacu pemasaran untuk menciptakan produk yang selain memberikan kualitas dan pelayanan juga memberikan pengalaman yang lebih kepada konsumen.

Lalu menurut Chaffey dan Bosomworth (2012:19) bentuk komunikasi pemasaran digital dibagi menjadi 3 hal:

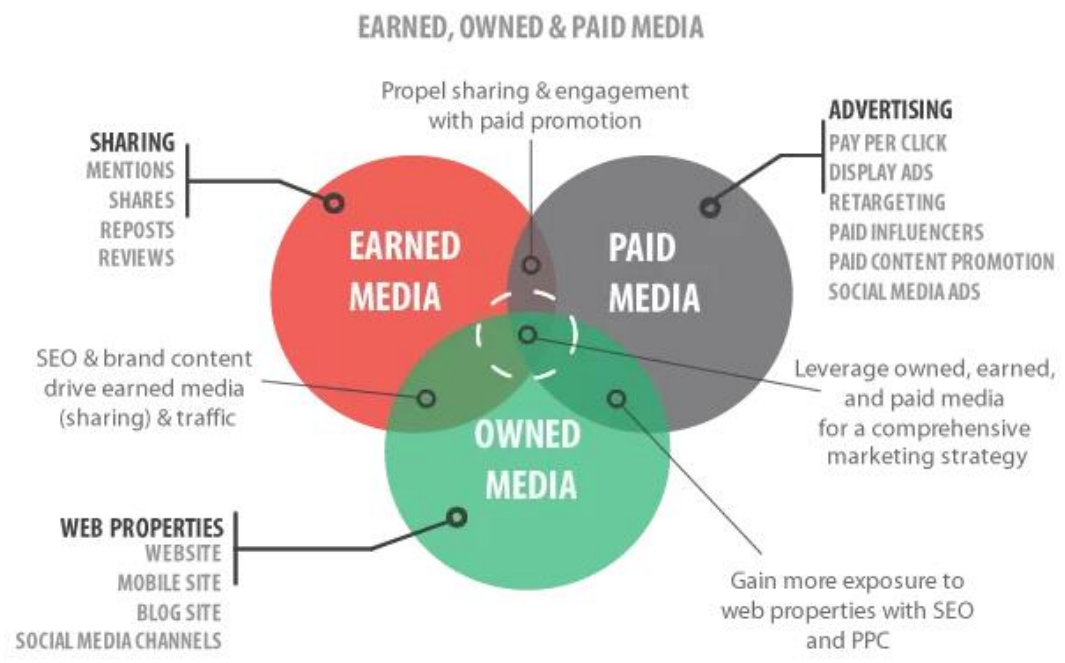

(Sumber: Dr Dave Chaffey and Danyl Bosomworth) 
Paid Media: "Simple. Paid or bought media are media where there is investment to pay for visitors, reach or conversions through search, display ad networks or affiliate marketing. Offline traditional media like print and TV advertising and direct mail remain important accounting for the majority of paid media spend." Paid Media adalah penggunaan properti yang dimiliki oleh pihak lain yang dibayar oleh perusahaan untuk membawa pesan promosi perusahaan. Contohnya, pemasangan iklan banner di media sosial, iklan baris online, display ads, dan lain-lain.

Earned media:"Traditionally, earned media has been the name given to publicity generated through $P R$ invested in targeting influencers to increase awareness about a brand. Of course, it's still an investment. Earned media also includes word-of-mouth that can be stimulated through viral and social media marketing and includes conversations in social networks, blogs and other communities. It's useful to think of earned media as developed through different types of partners such as publishers, bloggers and other influencers including customer advocates. Think of earned media as different forms of conversations occurring both online and offline. "Earned Media adalah pemaksimalan penggunaan pemasaran mulut ke mulut dalam dunia digital, menggunakan saluran yang diciptakan oleh konsumen yang ingin menyalurkan informasi mengenai brand perusahaan kepada konsumen lainnya, penyampaian ulasan konsumen maupun rating melalui sosial media atau biasa kita kenal dengan endorsment, buzzer, viral marketing.

Owned media: "This is media owned by the brand. Online this includes a company's own websites, blogs, mobile apps or their social presence on Facebook, Linked In or Twitter. Offline owned media may include brochures or retails stores." Owned Media adalah penggunaan alat-alat digital yang dimiliki atau dikontrol penuh oleh perusahaan antara lain web perusahaan, aplikasi yang dimiliki perusahaan, social media yang dimiliki perusahaan maupun penggunaan strategi search engine optimation (SEO) untuk membuat web perusahaan muncul di halaman awal Google Search Engine yang secara alami (tidak berbayar).

Media baru atau new media disebut juga media digital. Media digital adalah media yang kontennya berbentuk gabungan data, teks, suara, dan berbagai jenis gambar yang disimpan dalam format digital dan disebarluaskan melalui jaringan berbasis kabel optik broadband, satelit dan sistem transmisi gelombang mikro (Flew, 2008).

\section{Metode Penelitian}

Tahapan penelitian ini dimulai dengan melakukan pengumpulan data dengan cara observasi ke lapangan yaitu ST22 Consulting yang terletak di Plaza UOB, CoHive Sudirman, Jakarta. Penulis menempatkan diri sebagai Team Bussines Development. Metode penelitian yang digunakan adalah penelitian kualitatif dengan pendekatan studi kasus, yaitu mencari atau menjelajahi masalah dari satu kasus untuk mendapatkan gambaran secara menyeluruh dan mendalam tentang Bentuk Komunikasi Pemasaran Digital ST22 Consulting sebagai Konsultan Sponsorship di Indonesia. Peneliti mewawancarai key informant yaitu Ryan Batchin selaku Co Founder ST22 Consulting yang ahli di bidang digital marketing, untuk memperoleh informasi tentang bagaimana bentuk komunikasi pemasaran digital yang digunakan oleh ST22 Consulting. 
Pengumpulan data dalam penelitian ini dengan cara melakukan observasi, wawancara dengan key informant serta studi dokumentasi. Data penelitian hasil wawancara dicatat dan direkam selalui teknik pengamatan langsung dan wawancara mendalam. Dokumentasi juga digunakan sebagai teknik pengumpulan data penunjang. Hasil pengamatan dan wawancara yang diperoleh dari key informant kemudian dikumpulkan dan setelah dilakukan reduksi data.

Pada tahapan ini setelah data dipilah kemudian disederhanakan data yang tidak diperlukan disunting agar memberi kemudian dalam penampilan, penyajian serta kesimpulan sementara. Dalam proses analisis data, ketiga tahapan di atas yaitu reduksi data, penyajian data dan verifikasi berlangsung secara bersamaan dengan proses pengumpulan data. Setelah selesai melakukan penyajian data, penarikan kesimpulan dilakukan sebagai suatu kegiatan dari konfigurasi yang utuh.

\section{Hasil Temuan dan Diskusi}

Berdasarkan hasil obervasi, wawancara mendalam, observasi lapangan dan analisis terhadap bentuk komunikasi pemasaran digital pada ST22 Consulting, ditemukan hasil bahwa ST22 Consulting sebagai Konsultan Sponsorship di Indonesia, perlu melakukan kegiatan komunikasi pemasaran untuk memasarkan brand ST22 Consulting kepada masyarakat, menjalin interaksi, juga mengkomunikasikan produk maupun jasa yang ditawarkan khususnya kepada calon klien dan mitra usaha.

Hal pertama yang dilakukan oleh ST22 Consulting ialah menentukan target komunikasi pemasaran, yaitu anak muda. Setelah menentukan target komunikasi pemasaran, pesan dapat dirancang sesuai karakteristik target. Target komunikasi pemasaran ST22 Consulting adalah anak muda, pesan yang disampaikan harus relevan dan sesuai dengan sifat anak muda yang fun namun dinamis. Setelah menyusun pesan yang ingin disampaikan, ST22 Consulting menentukan media atau saluran komunikasi.

Didapat data Insight akun official instagram ST22 Consulting menunjukan bahwa usia khalayak yang menerima pesan mempunyai kisaran usia 18 hingga 24 tahun sebanyak 50\%. Diikuti dengan usia 25 hingga 34 tahun sebanyak 29\% lalu usia 13 hingga 17 tahun sebanyak 8\%. Maka konten atau pesan yang disampaikan juga mengikuti target komunikasi pemasaran. Konten yang dibuat ST22 Consulting bersifat fun dan tidak formal namun juga mengedukasi.

Setelah menentukan target komunikasi pemasaran, menyusun pesan dan menentukan saluran komunikasi, langkah selanjutnya ialah mengimplementasikan IMC. Menyusun strategi komunikasi pemasaran. Strategi komunikasi pemasaran yang digunakan oleh ST22 Consulting ialah acara dan pengalaman (event dan visit ke sekolah-sekolah) dan pemasaran interaktif (online atau digital).

Dalam melakukan komunikasi pemasaran digital, Ryan Batchin menyampaikan bahwa ST22 Consulting menggunakan beberapa bentuk komunikasi pemasaran sebagai berikut: Paid media ialah penggunaan properti yang dimiliki oleh pihak lain yang dibayar oleh perusahaan untuk membawa pesan promosi perusahaan. Contohnya, pemasangan iklan banner di media sosial, iklan baris online, display ads, dan lain-lain. ST22 Consulting memasang iklan berbentuk artikel di salah satu website lowongan pekerjaan yang related dengan anak muda atau biasa dikenal dengan Student Job. Hal ini adalah salah satu strategi komunikasi pemasaran digital dalam bentuk paid media. 
Selain menggunakan paid media, ST22 Consulting juga menggunakan bentuk komunikasi pemasaran yang dinamakan earn media. ST22 Consulting melakukan endorsment sebagai salah satu bentuk komunikasi pemasaran digital, earned media. Menggunakan salah satu account instagram yang diminati begitu banyak anak muda, yaitu kekomukan. Kegiatan endorsment ini disertai dengan kuis yang diadakan oleh ST22 Consulting, yang bertujuan untuk mengajak pada pengikut Instagram untuk mengunjungi instagram @st22consulting dan mengikuti kuis yang diadakan. Selain melakukan kegiatan endorsment, bentuk komunikasi pemasaran lainnya adalah earned media yang dilakukan oleh ST22 Consulting ialah buzzer. Kegiatan ini ialah menyampaikan ulasan kepuasan konsumen kepada konsumen lainnya, juga menyampaikan informasi mengenai brand perusahaan kepada konsumen lainnya. Teknik buzzer ini menggunakan salah satu klien ST22 Consulting sebagai testimoni.

Bentuk komunikasi pemasaran digital yang terakhir adalah owned media, penggunaan alat-alat digital yang dimiliki atau dikontrol penuh oleh perusahaan antara lain web perusahaan, aplikasi yang dimiliki perusahaan, social media yang dimiliki perusahaan maupun penggunaan strategi search engine optimation (SEO) untuk membuat web perusahaan muncul di halaman awal Google Search Engine yang secara alami (tidak berbayar). Bentuk komunikasi pemasaran owned media yang ST22 Consulting adalah pemaksimalan asset digital, ST22 Consulting mempunyai website yang dimana kontennya menyesuaikan dengan target audience yaitu anak muda. Sehingga desain dan isi kontennya ditujukan untuk anak muda.

Asset lain yang dimiliki oleh ST22 Consulting selain website adalah akun Instagram, yang dimana isi kontennya pun mengikuti target audience. Konten yang mengisi timeline Instagram @st22consulting berisi informasi tentang sponsorship, update tentang project-project yang sedang ditangani ST22 Consulting, actvation games atau kuis yang diadakan oleh ST22 Consulting, juga tips-tips untuk kehidupan sehari-hari anak muda.

Selain Website dan Instagram Asset lain yang dimiliki oleh ST22 Consulting ialah facebook, yang dimana isi kontennya pun mengikuti target audience. Konten yang mengisi timeline facebook @st22consulting berisi informasi tentang sponsorship, juga tips-tips untuk kehidupan sehari-hari anak muda. Lalu Youtube dan terakhirialah Line@.

ST22 Consulting menggunakan teknik SEO (Search Engine Optimization) sebagai bentuk komunikasi pemasaran digital, SEO adalah salah satu teknik owned media. SEO adalah teknik komunikasi pemasaran digital yang bertujuan untuk memunculkan atau menampilkan website ST22 Consulting di halaman pertama Google. Teknik SEO yang dilakukan ST22 Consulting ialah meggunakan hyperlink di artikel yang dimunculkan dalam website ST22 Consulting, juga memfokuskan keyword, meta description pada artikel.

Dalam melakukan kegiatan komunikasi pemasaran digital. Ternyata ST22 Consulting juga menemui beberapa kesulitan. Salah satunya ialah beberapa khalayak kurang mengerti mengenai konsultan sponsorship, sehingga cukup sulit untuk menjelaskan konsep dari ST22 Consulting. Konten harus dikemas sebaik mungkin agar khalayak dapat menerima pesan yang disampaikan, juga untuk brand yang mungkin belum memahami betul tentang keuntungan dari sponsorship. 
Penelitian ini juga melihat dari sisi klien ST22 Consulting. Berdasarkan wawancara penulis dengan beberapa narasumber didapatkan sebuah data, bahwa ternyata para klien justru mengetahui ST22 Consulting melalui Word Of Mouth, dimana menurut Philip Kotler dan Kevin Lane Keller (2009:189) pemasaran dari mulut ke mulut adalah komunikasi lisan, tertulis dan elektronik antar masyarakat yang berhubungan dengan keunggulan atau pengalaman membeli menggunakan produk atau jasa. Namun saat mereka ingin mencari tahu lebih jauh tentang ST22 Consulting, mereka melakukan pencarian melalui media digital seperti website, line official dan instagram.

Alasan utama mereka menggunakan jasa ST22 Consulting dikarenakan mereka melihat adanya testimoni di konten instagram ST22 Consulting, dan didukung dengan testimoni orang di sekitarnya. Selain itu, berdasarkan wawancara dengan narasumber, mereka mengaku puas dengan hasil kerjasama ST22 Consulting dan mereka akan merekomendasikan kepada adik kelas atau anak muda yang akan membuat suatu event.

\section{Simpulan}

ST22 Consulting memiiki target komunikasi pemasarannya merupakan anak muda, yang karena media komunikasi pemasaran utama adalah sosial media, terutama Instagram. Sedangkan dalam hal strategi komunikasi pemasaran yang paling utama digunakan oleh ST22 Consulting adalah acara dan pengalaman (event dan visit ke sekolah-sekolah) dan pemasaran interaktif (online atau digital). Bentuk komunikasi digital dilakukan dalam bentuk paid media, owned media, dan earned media.

\section{Ucapan Terima Kasih}

Ucapan terimakasih peneliti berikan kepada Ci Wulan Purnama Sari S.Ikom., M.Si, selaku pembimbing yang sangat amat sabar dalam membimbing penulis dalam menulis skripsi ini, Mas Ryan Batchin selaku Narasumber yang banyak memberi masukan, ilmu, materi, kepada penulis, juga kepada seluruh keluarga dan teman yang tidak pernah berhenti memberikan dukungan.

\section{Daftar Pustaka}

Arjanti, Restituta Ajeng dan Mosal, Reney Lendy. (2012). Startup Indonesia. Buku Kompas.

Chaffey, Dave \& Danyl Bossomworth. (2012). 7 Steps to Digital Marketing Strategy. Flew, T. (2008). New Media: An Introduction. New York: Oxford University Pers. Joseph, Thomas. (2011). APPS The Spirit of Digital Marketing 3.0. Jakarta: PT Elex Media Komputindo.

Kusniadji, Suherman. (2016). Strategi Komunikasi Pemasaran Dalam Kegiatan Pemasaran Produk Consumer Goods, (Studi Kasus Pada PT Expand Berlian Mulia Di Semarang). Jurnal Komunikasi UNTAR. <https://journal.untar.ac.id/index.php/komunikasi/article/view/1078/833> diunduh tanggal 28 Agustus 2018.

Percy, Larry. (2008). Strategic Intergrated Marketing Communication: Theory and Practice. USA : Elviser Inc. 
Mondry, (2008). Pemahaman Teori dan Praktik Jurnalistik. Bogor: Ghalia Indonesia.

Soemanagara, Rd. (2008). Marketing Communication. Bandung: Alfabeta. (http://beta286.print.kompas.com/ muda/2015/01/23/pensi-ajang-pamer/). 